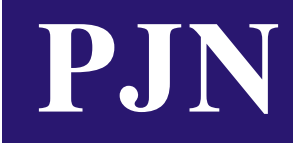

ISSN 1680-5194

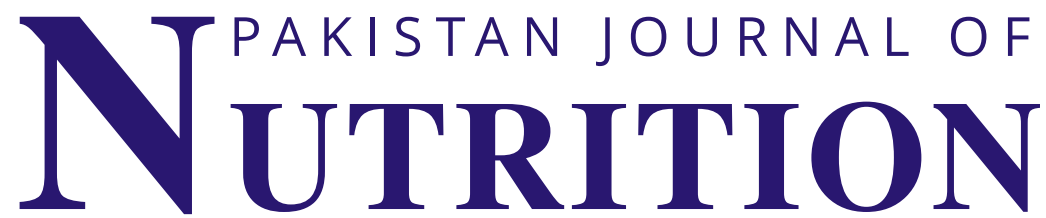

ANSI迫e佔

308 Lasani Town, Sargodha Road, Faisalabad - Pakistan Mob: +92 3003008585 , Fax: +92 418815544

E-mail: editorpjn@gmail.com 
Pakistan Journal of Nutrition 12 (10): 943-948, 2013

ISSN 1680-5194

(C) Asian Network for Scientific Information, 2013

\title{
Comparisons of Nutrient Contents and Nutritional Values of Palm Kernel Cake Fermented by Using Different Fungi
}

\author{
Yose Rizal, Nuraini, Mirnawati and Maria Endo Mahata \\ Faculty of Animal Science, Andalas University, Padang, West Sumatra, Indonesia
}

\begin{abstract}
An experiment has been conducted to compare the nutrient contents and nutritional values of palm kernel cake (PKC) from different fermentation processes. This experiment was designed in a Completely Randomized Design (CRD) with six treatments and five replicates. Treatments were $A=$ unfermented PKC (control), $\mathrm{B}=$ fermented PKC with Neurospora crassa, $\mathrm{C}=$ fermented PKC with Penicillium sp., $\mathrm{D}=$ fermented $\mathrm{PKC}$ with Trichoderma harzianum, $\mathrm{E}=$ fermented $\mathrm{PKC}$ with Aspergillus niger and $\mathrm{F}=$ fermented $\mathrm{PKC}$ with Aspergillus niger+humic acid. Measured variables were nutrient contents (crude protein, crude fiber and ether extract) and nutritional values (nitrogen retention, crude fiber digestibility and metabolizable energy) of fermented and unfermented PKCc. Results of experiment indicated that the crude fiber content of fermented PKCs was very significantly lower $(p<0.01)$ than that of control, but there was no difference $(p>0.05)$ among the fermented PKCs. Fermentation with different fungi increased $(p<0.05)$ the crude protein content of PKCs when it was compared with control. The crude protein content of Aspergillus niger and Aspergillus niger+humic acid fermented PKCs were significantly higher $(p<0.05)$ than that of Trichoderma harzianum, Neurospora crassa, or Penicillium sp., fermented PKCs or control. The ether extract content of PKC was very significantly affected $(\mathrm{p}<0.01)$ by treatments. Aspergillus niger+humic acid, Neurospora crassa and Aspergillus niger fermented PKCs possessed the lower ether extract content $(p<0.05)$ than that of Penicillium sp., or Trichoderma harzianum fermented PKCs, or control. The crude fiber digestibility of Aspergillus niger or Aspergillus niger+humic acid fermented PKCs was very significantly higher $(p<0.01)$ than that of Penicillium sp., Trichoderma harzianum, Neurospora crassa fermented PKCs, or control. The nitrogen retention of Aspergillus niger+humic acid fermented PKC was significantly higher $(p<0.05)$ than that of Penicillium sp., Neurospora crassa fermented PKCs, or control, but was not differed $(p>0.05)$ from that of Trichoderma harzianum or Aspergillus niger fermented PKCs. The fermentation with different fungi improved $(p<0.05)$ the metabolizable energy content of PKC. Thus, the improvement of the nutrient contents and nutritional values of Aspergillus niger fermented PKC was better than the other treatments.
\end{abstract}

Key words: Palm kernel cake, fermentation, Aspergillus niger, humic acid, Penicillium sp., Trichoderma harzianum, Neurospora crassa, nutrient content, nutritional value

\section{INTRODUCTION}

Indonesia is the biggest producer of crude palm oil in the world with the total production of 22.5 million tones per year. Seventy percent of the total production of crude palm oil was located in Sumatra Island (BPS, 2010). With the development of palm oil plantation, it will produce a huge amount of waste or by-product of palm oil industry in the form of Palm Kernel Cake (PKC) because $45-46 \%$ of the by-product of palm oil industry is PKC.

The nutrient content of PKC was as follows: crude protein $16,07 \%$, crude fiber $21,30 \%$, ether extract $8.23 \%$, Ca $0.27 \%, \mathrm{P} 0.94 \%$ and $\mathrm{Cu} 48.4 \mathrm{ppm}$ (Mirnawati et al., 2008), so that it can be utilized as an animal feed. Even though its crude protein content was rather high, its utilization in poultry diets was not optimal yet. According to Supriyadi (1997) the PKC could be included up to $10 \%$ in the duck ration and Rizal
(2000) found that PKC could be utilized up to $10 \%$ in the broiler diet to effectively replace $40 \%$ soybean meal. The low in the utilization of PKC in poultry diets was due to the low in the nutritive value of this PKC. The low in nutritive value of PKC was related to the high in crude fiber content, low amino acids content and the high in $\mathrm{Cu}$ content (Nwokolo et al., 1976; Ezhieshi and Olomu, 2004; Mirnawati et al., 2008) and high in $\beta$-manan or mannose polymere (Dusterhof et al., 1993; et al., 2007). On the other hand, the ability of poultry to digest crude fiber is limited (Scott et al., 1982).

For increasing the utilization of PKC in poultry diets, the processing through fermentation had been performed by using cellulolytic microbes such as: Trichoderma harzianum, Aspergillus niger and Penicillium sp. (Sabrina et al., 2001; Nuraini and Yunara, 2001; Aziz et al., 2003; Harnentis et al., 2005; Mirnawati et al., 2008), proteolytic such as: Rhizopus sp. (Sabrina et al.,

Corresponding Author: Yose Rizal, Faculty of Animal Science, Andalas University, Padang, West Sumatra, Indonesia 
Pak. J. Nutr., 12 (10): 943-948, 2013

2001) and carotenogenic such as: Neurosphora sp. (Sabrina et al., 2001; Nuraini and Susilawati, 2006). Poultry response to the utilization of fermented PKC ranging from 15 to 25\% (Sabrina et al., 2001; Nuraini and Trisna, 2006; Nuraini et al., 2007).

The nutrient content, nutritional value and poultry response to the utilization of fermented PKC are still varied, so that it is still necessary to further study the nutrient quality of processed $\mathrm{PKC}$, so that it can be utilized in large amount in poultry diets and is available continuously in the market in the form of complete diets ready for feeding to poultry.

\section{MATERIALS AND METHODS}

This experiment was aimed to study the effect of fermentation by using different species of fungi on the nutrient contents and nutritional values of PKC and to find out the best fungi for fermenting the PKC through the utilization of Neurospora crassa, Penicillium sp., Trichoderma harzianum and Aspergillus niger. They were also compared with the unfermented PKC. A Completely Randomized Design (CRD) with 6 treatments and 5 replicates was employed in this experiment. The treatments were $\mathrm{A}=$ unfermented $\mathrm{PKC}$ (control), $\mathrm{B}=$ Neurospora crassa fermented PKC, $\mathrm{C}=$ Penicillium $s p$. fermented $\mathrm{PKC}, \mathrm{D}=$ Trichoderma harzianum fermented $\mathrm{PKC}, \mathrm{E}=$ Aspergillus niger fermented $\mathrm{PKC}$ and $\mathrm{F}=$ Aspergillus niger+humic acid fermented PKC.

The fermentation of PKC by using Neurospora crassa was performed with the inoculums dose of $9 \%$ and fermentation length of 5 days, Penicillium sp. with inoculums dose of $6 \%$ and fermentation length of 7 days, Trichoderma harzianum with the inoculums dose of $8 \%$ and fermentation length of 7 days, Aspergillus niger with the inoculums dose of $10 \%$ and fermentation length of 7 days and Aspergillus niger+100 ppm humic acid with the inoculums dose of $10 \%$ and fermentation length of 7 days. The total amount of substrate used for each treatment was $100 \mathrm{~g}$, consisted of $80 \mathrm{~g}$ of PKC plus $20 \mathrm{~g}$ of rice bran.

Measured variables were nutrient contents (crude fiber, crude protein and ether extract) and nutritional values (crude fiber digestibility, nitrogen retention and metabolizable energy content) of fermented and unfermented PKCs. Crude fiber, crude protein and ether extract were determined according to proximate analysis procedures (AOAC, 1984). Crude fiber digestibility was measured according to Schneider and Flatt (1975). Nitrogen retention and metabolizable energy were performed according to McDonald (1981) and Sibbald (1975), respectively.

Data were analyzed by analysis of variance of CRD. Duncan Multiple Range Test (DMRT) according to Steel and Torrie (1980) was performed for testing the difference among treatments.

\section{RESULTS}

Effect of treatments on the crude fiber content of palm kernel cake: The means of crude fiber content of fermented and unfermented PKCs were illustrated in Table 1.

The result of the analysis of variance indicated that the crude fiber content of PKC was very significantly $(p<0.01)$ influenced by the treatments. The crude fiber of PKC fermented with Neurospora crasa, T. harzianum, Phenicillium sp., Aspergillus niger, or Aspergillus niger+humic acid was not differed ( $p>0.05$ ). However, the crude fiber content of all fermented PKCs was very significantly lower than that of unfermented PKC.

\section{Effect of treatments on crude protein content of palm} kernel cake: The effect of treatments on the crude protein content of PKC was figure out in Table 2. The crude protein content of PKC was very significantly affected $(p<0.01)$ by treatments.

The crude protein content of Aspergillus niger fermented PKC was not differed from Aspergillus niger+humic acid fermented PKC, but was higher $(p<0.05)$ than those of Penicillium sp., Trichoderma harzianum and Neurospora crassa fermented PKCs as well as unfermented PKC. The crude protein content of Aspergillus niger + humic acid fermented PKC was higher $(\mathrm{p}<0.05)$ than those of Trichoderma harzianum and Neurospora crassa fermented PKCs as well as unfermented PKC, but was not different from Penicillium $s p$. fermented PKC. Penicillium sp. fermented PKC crude protein content was not differed from Trichoderma harzianum fermented PKC, but was higher than those of

Table 1: Crude fiber content of palm kernel cake as affected by treatments

\begin{tabular}{lc}
\hline Treatments & Crude fiber (\%) \\
\hline A (Control) & $18.86^{\mathrm{a}}$ \\
B (Neurospora crassa) & $14.75^{\mathrm{b}}$ \\
C (Penicillium sp.) & $13.42^{\mathrm{b}}$ \\
D (Trichodema Harzianum) & $14.04^{\mathrm{b}}$ \\
E (Aspergillus niger) & $14.34^{\mathrm{b}}$ \\
F (Aspergillus niger + Humic Acid) & $13.98^{\mathrm{b}}$ \\
SEM $^{\star}$ & 0.68 \\
\hline
\end{tabular}

a,b Means with different superscript are very significantly different $(p<0,01) .{ }^{\star}$ Standard Error of the Mean

Table 2: Crude protein content of palm kernel cake as affected by treatments

\begin{tabular}{lc}
\hline Treatments & Crude protein (\%) \\
\hline A (Control) & $23.30^{\mathrm{e}}$ \\
B (Neurospora crassa) & $24.49^{\mathrm{de}}$ \\
C (Penicillium sp.) & $26.34^{\mathrm{bc}}$ \\
D (Trichoderma harzianum) & $26.21^{\mathrm{cd}}$ \\
E (A. niger) & $28.41^{\mathrm{a}}$ \\
F $(A$. niger + Humic Acid) & $28.06^{\mathrm{ab}}$ \\
SEM $^{\star}$ & 0.59 \\
\hline
\end{tabular}

$a, b, c, d, e$ Means with different superscripts are significantly different $(p<0.05) .{ }^{*}$ Standard Error of the Mean 
Pak. J. Nutr., 12 (10): 943-948, 2013

Neurospora crassa fermented PKCs as well as unfermented PKC. Trichoderma harzianum fermented PKC was not differed from Neurospora crassa fermented $\mathrm{PKC}$, but was higher than that on unfermented PKC. The crude protein content of Neurospora crassa fermented $\mathrm{PKC}$ was not different from unfermented PKC.

Effect of treatments on ether extract content of palm kernel cake: The means of the ether extract content of fermented and unfermented PKC can be seen in Table 3. The treatments affected the ether extract content of PKC very significantly $(p<0.01)$.

The ether extract content of unfermented PKC (control) was very significantly higher $(p<0.01)$ than those of fungi fermented PKCs. Penicillium sp. fermented PKC ether extract content was higher $(p<0.05)$ than that of Trichoderma harzianum fermented PKC and was very significantly higher $(p<0.01)$ than those of Aspergillus niger, Neurospora crassa and Aspergillus niger+humic acid fermented PKCs and unfermented PKC. The ether extract content of Trichoderma harzianum fermented PKC was not different ( $p>0.05$ ) from those Aspergillus niger and Neurospora crassa fermented PKCs, but was higher $(p<0.05)$ than that Aspergillus niger+humic acid fermented PKC. There was no difference $(p>0.05)$ in the ether extract content of Aspergillus niger, Neurospora crassa and Aspergillus niger+humic acid fermented PKCs.

Effect of treatments on the crude fiber digestibility of palm kernel cake: The means of the crude fiber digestibility of fermented and unfermented PKC was seen in Table 4.

Results of the experiment indicated that treatments very significantly influenced the crude fiber digestibility of PKCs. This crude fiber digestibility of Aspergillus niger and Aspergillus niger+humic acid fermented PKCs was not differed $(p>0.05)$, but was significantly higher $(p<0.01)$ than those of Neurospora crasa, Trichoderma harzianum and Penicillium sp. fermented PKCs and unfermented PKC. The Neurospora crassa fermented $P K C$ crude fiber digestibility was higher $(p<0.05)$ than those of Trichoderma harzianum and Penicillium sp., fermented PKCs and was very significantly higher $(p<0.01)$ than that of unfermented PKC. There was no difference in crude fiber digestibility between Trichoderma harzianum and Penicillium sp., fermented PKCs. However, both of them were differed $(p<0.01)$ from control.

Effect of treatments on the nitrogen retention of palm kernel cake: The effect of treatments on the nitrogen retention of fermented and unfermented PKC was depicted in Table 5. Treatments influenced the nitrogen retention of fermented and unfermented PKCs significantly $(p<0.05)$.
Table 3: Ether Extract Content of Palm Kemel Cake as Affected by Treatments

\begin{tabular}{lc}
\hline Treatments & Ether extract (\%) \\
\hline A (Control) & $9.18^{\mathrm{a}}$ \\
$\mathrm{B}$ (Neurospora crassa) & $2.78^{\text {cd }}$ \\
C (Penicillum sp.) & $4.39^{\mathrm{b}}$ \\
D (Trichoderma harzianum) & $3.35^{\mathrm{c}}$ \\
E $($ A. niger) & $3.00^{\mathrm{d} d}$ \\
F $(A$. niger + Humic Acid) & $2.34^{d}$ \\
SEM $^{\star}$ & 0.25 \\
\hline
\end{tabular}

$a, b, c, d$ Means with different superscripts are significantly different $(p<0.05) .{ }^{*}$ Standard Error of the Mean

Table 4: Crude fiber digestibility of palm kernel cake as affected by treatments

\begin{tabular}{lc}
\hline Treatments & $\begin{array}{c}\text { Crude fiber } \\
\text { digestibility (\%) }\end{array}$ \\
\hline A (Control) & $12.02^{\mathrm{d}}$ \\
B (Neurospora crasa) & $27.89^{\mathrm{b}}$ \\
C (Trichoderma harzianum) & $23.48^{\mathrm{c}}$ \\
D (Penicillum sp.) & $22.40^{\mathrm{c}}$ \\
E (Aspergillus niger) & $38.71^{\mathrm{a}}$ \\
F (Aspergillus niger + Humic Acid) & $40.86^{\mathrm{a}}$ \\
$\mathrm{SEM}^{\star}$ & 4.23 \\
\hline
\end{tabular}

$a, b, c, d$ Means with different superscripts are very significantly different $(p<0.01)$. Standard Error of the Mean

Table 5: Nitrogen retention of palm kernel cake as affected by treatments

\begin{tabular}{lc}
\hline Treatments & Nitrogen retention (\%) \\
\hline A (Control) & $18.67^{\mathrm{c}}$ \\
B (Neurospora crassa) & $28.44^{\mathrm{c}}$ \\
C (Penicillium sp.) & $34.48^{\mathrm{bc}}$ \\
D (Trichoderma harzianum) & $56.40^{\mathrm{ab}}$ \\
E (A. niger) & $42.31^{\mathrm{abc}}$ \\
F $($ A. niger + Humic Acid) & $63.73^{\mathrm{a}}$ \\
$\mathrm{SEM}^{\star}$ & 8.26 \\
\hline
\end{tabular}

$a, b, c$ Means with different superscripts are significantly different $(p<0.05) .{ }^{*}$ Standard Error of the Mean

Table 6: Metabolizable energy of palm kernel cake as affected by treatments

\begin{tabular}{lc}
\hline Treatments & Metabolizable \\
\hline A (Control) & Energy (Kcal/Kg) \\
B (Neurospora crasa) & $2252^{\mathrm{b}}$ \\
C (Trichoderma harzianum) & $2368^{\mathrm{a}}$ \\
D (Penicillium sp.) & $2371^{\mathrm{a}}$ \\
$\mathrm{E}$ (Aspergillus niger) & $2404^{\mathrm{a}}$ \\
$\mathrm{F}$ (Aspergillus niger+Humic Acid) & $2411^{\mathrm{a}}$ \\
SEM $^{\star}$ & $2424^{\mathrm{a}}$ \\
\hline
\end{tabular}

$a, b$ Means with different superscripts are significantly different $(p<0.05)$. *Standard Error of the Mean

The nitrogen retention of the Aspergillus niger+humic acid, Trichoderma harzianum and Aspergillus niger fermented PKCs was significantly higher $(p<0.05)$ than those of Penicillium sp. and Neurospora crassa fermented PKCs and control, but it was not different among them. The Penicillium sp., fermented PKC nitrogen retention was not different $(p<0.05)$ from Neurospora crassa fermented PKC and unfermented 
PKC. The nitrogen retention of Neurospora crassa fermented PKC was also statistically the same as the unfermented PKC.

Effect of treatments on the metabolizable energy of palm kernel cake: The means of the metabolizable energy content of fermented PKC by using different species of fungi and unfermented PKC are depicted in Table 6.

Based on the result of analysis of variance, the fermentation by using different kind of microbes significantly affected $(p<0.05)$ the metabolizable energy content of PKC. The metabolizable energy content of Neurospora crasa, $T$. harzianum, Penicillium sp., Aspergillus niger, Aspergillus niger+asam humat fermented PKCs was higher $(p<0.05)$ than the unfermented PKC.

\section{DISCUSSION}

Effect of treatments on the crude fiber content of palm kernel cake: The low in crude fiber of PKC after fermented with Neurospora crasa, T. harzianum, Penicillium sp. and Aspergillus niger, was due to the cellulolytic characteristics of these fungi which posses high cellulase activity (Mirnawati et al., 2011), so that they can degrade cellulose into glucose which in turn at the end of fermentation process the declining in crude fiber occurs. The result of the reduction of crude fiber was in accordance with the results of experiments by Sabrina et al. (2002) and Nuraini and Yunara (2001).

Effect of treatments on crude protein content of palm kernel cake: When it was compared with the unfermented PKC (control), there was an increase in crude protein content of fermented PKCs (treatments $B$, $C, D, E$ and $F$ ). It was clearly found that there was the growth of fungi in each fermented PKC. The growing fungi contribute to the increase in crude protein content of $\mathrm{PKC}$, so that there was an augmenting in crude protein of fermented PKC. Crueger and Crueger (1989) reported that fungi contained high crude protein (40-60\%). According to Carlile and Watkinson (1995), the increase in crude protein content of substrate after fermentation was associated with the process of protein enrichment which was similar to the formation of a single cell protein and in this process it was not separated between protein from fungi and substrate.

The height in crude protein content of PKC Aspergillus niger, Aspergillus niger+humic acid, Penicillium sp. and Trichoderma harzianum fermented PKCs was also related to the enzymes (cellulase, protease, etc.) produced by these fungi as the protein which could contribute to the height in crude protein content of the $\mathrm{PKC}$ as compared with Neurospora crassa fermented PKC and control. According to Hidayat (2007) fermentation is the activity of microbes in food or feed to produce high quality products through increasing the nutrient content and nutritional value of the products.

\section{Effect of treatments on ether extract content of palm} kernel cake: There was a reduction of ether extract content when the PKC was fermented by using fungi. The dramatic decreased in ether extract content of PKC occurred at the fermentation by using Aspergillus niger, Neurospora crassa and Aspergillus niger+humic acid. According to Falony et al. (2006) fungi was known a microbe which produce high lipase and Aspergillus niger was one of fungi that produce high amount of lipase. Penicillium $s p$. was also a high lipase producer (Pimentel et al., 1997; Lima et al., 2003). Ulker et al. (2010) found that Trichoderma harzianum was also a fungi which produce lipase. Neurospora crassa was also well known as a lipase producer (Kundu et al., 1987). Thus, the lipase produced by each fungi could hydrolyze lipid content in fermented PKC, so that the ether extract/lipid content of fermented PKC declined.

Effect of treatments on the crude fiber digestibility of palm kernel cake: The crude fiber digestibility among Neorospora crasa, A. niger and A niger+humic acid fermented PKC was relatively high. This was due to the height in cellulolytic activity of these species of fungi. The higher the cellulolytic activity of the fungi, the more cellulose could be degraded into glucose, so that at the end of fermentation the amount of crude fiber decreased. This finding was in accordance with the results of experiments by Nuraini and Susilawati (2006) and Mirnawati et al. (2010) who reported that there was a decline in crude fiber content of PKC fermented by using Neorospora crassa and Aspergillus niger.

Effect of treatments on the nitrogen retention of palm kernel cake: The height in nitrogen retention of Aspergillus niger+humic acid fermented PKC was related to the height in crude protein of this fermentation product $(28.06 \%)$, so that the amount of protein consumed increased. The high amount of protein consumed resulted in the high in retained nitrogen in the body which could be utilized by animals. According to Farrell (1974) the nitrogen retention was the retained feed protein in the animal body. The nitrogen retention was influenced by several factors such as crude protein content of feed, amino acid content and protein digestibility. Lloyd et al. (1978) said that nitrogen retention was one of methods for determining the protein quality of feed or diet.

Effect of treatments on t he metabolizable energy of palm kernel cake: The metabolizable energy (ME) of fermented PKC by using Neurospora crassa, Trichoderma harzianum, Penicillium sp., Aspergillus niger and Aspergillus niger + humic acid was higher 
than that of unfermented PKC (control). The increase in this ME was resulted from the fermentation process which lead to the degradation of crude fiber into the simple carbohydrates. These simple carbohydrates are readily digested and absorbed by animals. Fardiaz (1989) reported that the biosynthesis of macromolecules such as protein, lipid, polysaccharide and nucleic acid was originally produced from variety of monomer units such as amino acids, fatty acids, simple carbohydrates, etc.

The result of this experiment was also in accordance with the result of experiment by Desserheine (1998) who reported that there was an increase in ME of PKC which was fermented by using Aspergillus niger from 1844 to $2103 \mathrm{kcal} / \mathrm{kg}$. The increase in the ME content of Aspergillus niger fermented PKC was due to the increase in the crude fiber digestibility of this fermented PKC which produced simple sugars as the source of energy by animals.

Conclusion: The fermentation of palm kernel cake by using Aspergilus niger was the best when it was compared with the fermentation by using Neurospora crasa, Trichoderma harzianum, Penicillium sp. or Aspergillus niger+humic acid, or without fermentation (control).

\section{ACKNOWLEDGEMENTS}

This experiment was supported by the MP3El Funding Program provided by Directorate General of Higher Education, Ministry of Education and Culture of the Republic of Indonesia. I am very grateful to the Dean of the Faculty of Animal Science, the Head of Research and Extension Institute and the Rector of the University of Andalas who have given me a chance to compete with others in obtaining this funding. My special thanks is also directed to the Director General of Higher Education and the Minister of Education and Culture who have provided this funding.

\section{REFERENCES}

AOAC, 1984. Official Methods of Analysis (14th Ed.). Association of Official Analytical Chemists, Washington, DC.

Aziz, A., S. Gan, S.H. Hasan, M.A. Karim and S. Noraini, 2003. Biomass Estimation and Growth Aspergillus niger in solid state fermentation on Palm Kernel Cake in: Proseeding of 14th National biotecnology Seminar Desember 11-13 Penang, Malaysia, pp: 59.

BPS, 2010. Indonesian Statistics. Center Bearau of Statistics, Jakarta.

Carlile, M.J. and S.C. Watkinson, 1995. The Fungi. Academic Press Inc., London.

Crueger, W. and A. Crueger, 1989. Biotechnology: A Text of Industrial Microbiology. Sinauer Assoc. Inc., USA.
Desserheine, S.D.S., 1998. The utilization of Aspergillus niger for improving nutritional values of palm kernel cake in the diet of broilers. Thesis. Pascasarjana IPB, Bogor.

Dusterhoft, E.M., A.W. Bonte and A.G.J. Voragen, 1993. Solubilisation of non-starch polysaccharides from oil seed meals by polysacharide degrading enzymes. J. Sci. Food and Agric., 63: 211-220.

Ezhieshi, E.V. and J.M. Olomu, 2004. Nutritional evaluation of palm kernel meal types: 2 . Effects on live performance and nutrient retention in broiler chicks diets. Afr. J. Biotechnol., 7: 1171-1175.

Falony, G., J.C. Armas, J.C.D. Mendoza and J.L.M. Hernández, 2006. Production of Extracellular Lipase from Aspergillus niger by Solid-State Fermentation. Food Technol. Biotechnol., 44: 235-240.

Fardiaz, S., 1989. Food Microbiology. PAU IPB and LSI IPB, Bogor.

Farrell, D.J., 1974. General principles and assumptions of calorimetry. Pages 1-24 in Energy Requirements of Poultry. T.R. Morris and B.M. Freeman, ed. British Poultry Sci. Ltd., Edinburgh, UK

Harnentis, Mirnawati and Mirzah, 2005. Palm kernel cake processing technology for increasing its utility in poultry diets. Competitive Grant Research Report XIII. Ministry of Education and Culture, Indonesia.

Hidayat, 2007. Fermentation and Its Application. PT. Gramedia Pustaka Utama, Jakarta.

Kundu, M., J. Basu, M. Guchhait and P. Chakrabarti, 1987. Isolation and characterization of an extracellular lipase from the conidia of Neurospora crassa. J. Gen. Microbiol., 133, pp: 149-153.

Lima, V.M.G., N. Krieger, M.I.M. Sarquiz, D.A. Mitchell, L.P. Ranos and J.D. Fontana, 2003. Effect of nitrogen and carbon sources on lipase production by Penicillium, aurantiogriseum. Food Technology and Biotechnol., 41: 105-110.

Lloyd, L.E., B.E. McDonald and E.W. Crampton, 1978. Fundamentals of Nutrition, 2nd edn. WH. Freeman, San Francisco.

McDonald, P., R.A. Edwards and J.F.D. Greenhalgh, 1981. Animal Nutrition. Third Ed. Longman Inc., New York.

Mirnawati, I. Putu Kompiang and Harnentis, 2008a. The role of humic acid as heavy metal scavenger in processing palm kernel cake for poultry feed. Competitive Grant Research Report. Ministry of Education and Culture, Indonesia.

Mirnawati, I. Putu Kompiang and Harnentis, 2008b. The role of humic acid as heavy metal scavenger in processing palm kernel cake for poultry feed. Competitive Grant Research Report. Ministry of Education and Culture, Indonesia.

Mirnawati, Y. Rizal, I. Putu Kompiang and Y. Marlida, 2010. The role of humic acid in palm kernel cake fermented by Aspergillus niger for poultry ration. Pak. J. Nutr., 9: 182-185. 
Mirnawati, Y. Rizal, I. Putu Kompiang and Y. Marlida, 2011. Improving the quality of palm kernel cake content as poultry feed through fermentation by combination with various microbe and humic acid. Prociding Seminar International AINI. UNPAD. Bandung.

Nuraini and Yunara, 2001. Increasing the nutrient quality of palm kernel cake through fermentation by using Penicillium sp. Jurnal Andalas Edisi Pertanian No 36/ Mei/ ThXIII.

Nuraini and A. Trisna, 2006. The response of broilers on the ration containing Penicillium sp., fermented palm kernel cake. Jurnal Agribisnis Peternakan (Agripet) USU, Medan, 2: 45-48.

Nuraini and Susilawati, 2006. The nutrient content Neurospora crassa fermented palm kernel cake. Research Report. Fakultas Peternakan Universitas Andalas.

Nuraini, Siswanti and Widodo, 2007. Production performance and egg quality of hens receiving diets containing Neurospora crassa fermented palm kernel cake. J. Agribisnis Peternakan (Agripet) USU, Medan, 2: 55-59.

Nwokolo, E.N., D.B. Bragg and S.S. Saben, 1976. The availability of amino acids from palm kernel, soybean, cotton seed and rape seed meal for the growing chick. Poult. Sci., 55: 2300-2304.

Pimentel, M.C.B., E.H. M. Melo, F.J.L. Lima, W.M. Ledingham and $N$. Duran, 1997. Lipase from Brazilian strain Penicillium citrinum cultured in a simple inexpensive medium. Applied Biochem. Biotechnol., 66: 185-195.

Rizal, Y., 2000. The response of broilers to the substitution part of soybean meal for palm kernel cake in the diet. J. Peternakan dan Lingkungan, 2 : 15-20.
Sabrina, Nuraini, M.H. Abbas and R. Zein, 2001. Improving the nutrient quality of palm kernel cake through biotechnological approach by using several fungi. Competitive Grant Research Report. Ministry of Education and Culture, Indonesia.

Sabrina, Nuraini, M.H. Abbas and R. Zein, 2002. The utilization of Pemanfaatan bungkil inti sawit fermentasi dengan Trichoderma harzianum fermented palm kernel cake as poultry feed. Competitive Grant Research Report. Ministry of Education and Culture, Indonesia.

Schneider, B.H. and W.P. Flatt, 1975. The evaluation of feeds through digestibility experiments. University of Georgia Press, Athens.

Scott, M.L., M.C. Nesheim and R.J. Young, 1982. Nutrition of the Chicken. Third Edition. M. L. Scott and Associates, Ithaca, New York.

Sibbald, I.R., 1975. The measurement of metabolizable energy for poultry feeding stuffs. Proc. Arkansas Nutr. Conf., Fayetteville, USA.

Steel, R.G.D. and J.H. Torrie, 1980. Priciples and Procedures Statistics: A Biometrical Approach. McGraw Hill Book Co., New York.

Supriyadi, 1997. The effect of palm kernel cake utilization in the diet on the physiological organ of growing ducks. Skripsi. Fakultas Peternakan, Universitas Andalas, Padang.

Tafsin, M., L. A. Sofyan, N. Ramli, K. W. Wiryawan, K. Zarkasie and W. G. Piliang. 2007. Polysaccharide mannan of palm kernel cake anti microbial agent for Samonella thypimurium in the chicken. Media Peternakan J. Anim. Sci., Bogor Agricultural Institute, 30: 139-146.

Ulker, S., A. Ozel, A. Colak, S.A. Karaoglu, 2010. Isolation, production and characterization of an extracellular lipase from Trichoderma harzianum isolated from soil. Turk. J. Biol., 35: 543-550. 